\title{
TIAGO BAPTISTA: HISTÓRIAS DE HOMENS E LENDAS DA PINTURA
}

\author{
Susana Rocha
}

\section{Resumo}

O presente artigo pretende dar a conhecer uma perspectiva individual do trabalho plástico do artista Tiago Baptista. Nele encontramos uma profunda relação com um universo de preocupações que se centralizam na identificação das nossas falhas humanas. Neste vasto contexto são convocadas antigas lendas da História da Pintura e são pressentidas variadas referências de autores que integram essa mesma história. Partindo da praxis do próprio autor, das suas palavras, e das palavras que outros construíram a partir das suas representações ambíguas, importa perceber como a simbiose das questões enumeradas sustentam as imagens criadas por Baptista.

\section{Palavras-chave:}

Tiago Baptista, Falhas Humanas, Lendas da Pintura, Fracasso.

\begin{abstract}
Recorro ao uso de um espaço "arruinado" à "omnipresença da ruína", a lugares que não existem, que são quase lugares do nada, sítios sem função, que foram projectados para determinada acção mas que ficaram desprovidos da sua função a meio do processo civilizacional, a meio de um projecto de desenvolvimento. [...]

É a partir desta ideia de falha, de interrupção de um processo, de um projecto: um projecto social, político, cultural, religioso, de construção daquilo que é a nossa índole, a nossa personalidade, a nossa existência enquanto seres individuais e colectivos, que tento, no fundo, ter presente a ideia de que há uma falha na construção do projecto que somos nós. (Baptista, 2011: Maio)
\end{abstract}

Nascido em Leiria (Portugal) em 1986, Tiago Baptista tem vindo a construir um percurso socialmente envolvido, recorrendo à realidade que Ihe é mais familiar: os lugares, as fisionomias, as pessoas, as histórias... As suas palavras ressoam em cada tela, e com atenção, podemos também por lá encontrar Portugal, os seus afectos e algumas

\section{Abstract}

This article aims to present an individual perspective on Tiago Baptista's work. In it, we find a deep relationship with a universe of concerns related with the identification of our human flaws. In this wider context old legends about the History of Painting are called upon his work, mixed with several references of notable artists who integrate that same history. Through the praxis of this author, through his own words, and the words that others have found faire to create about this ambiguous representations, it is important to understand this specific symbiosis which supports the images made by Baptista.

\section{Keywords:}

Tiago Baptista, Human Flaws, Legends of Painting, Failure.

lendas basilares da história da pintura.

A partir da ideia de uma falha social, de uma civilização fracassada, de um mundo por cumprir povoado por anti-heróis, Tiago Baptista cria imagens que se instalam em nós e provocam uma sensação de familiaridade primitiva, materializando representações escondidas das nossas inquietações, onde o absurdo se funde com a realidade.

Por ocasião da sua exposição "O que fazer com isto?" na Galeria 3+1 em Lisboa, em 2012, Catarina Domingues, que conhece profunda e intimamente as questões que ocupam o universo criado por Tiago Baptista, escrevia num pequeno livro de sala: Ao longe a paisagem desmoralizada. A ruína dos valores estranhamente assumida na ruína de um colectivo. Lugares transformados em não lugares, a imobilidade, a passividade, os edifícios que repousam solitariamente. O gesto esquecido do homem. Os lugares adormecidos no tempo, a consciência dessa dormência colectiva, o nada à espera de acontecer. (...) O homem edificou cidades, definiu propriedades 


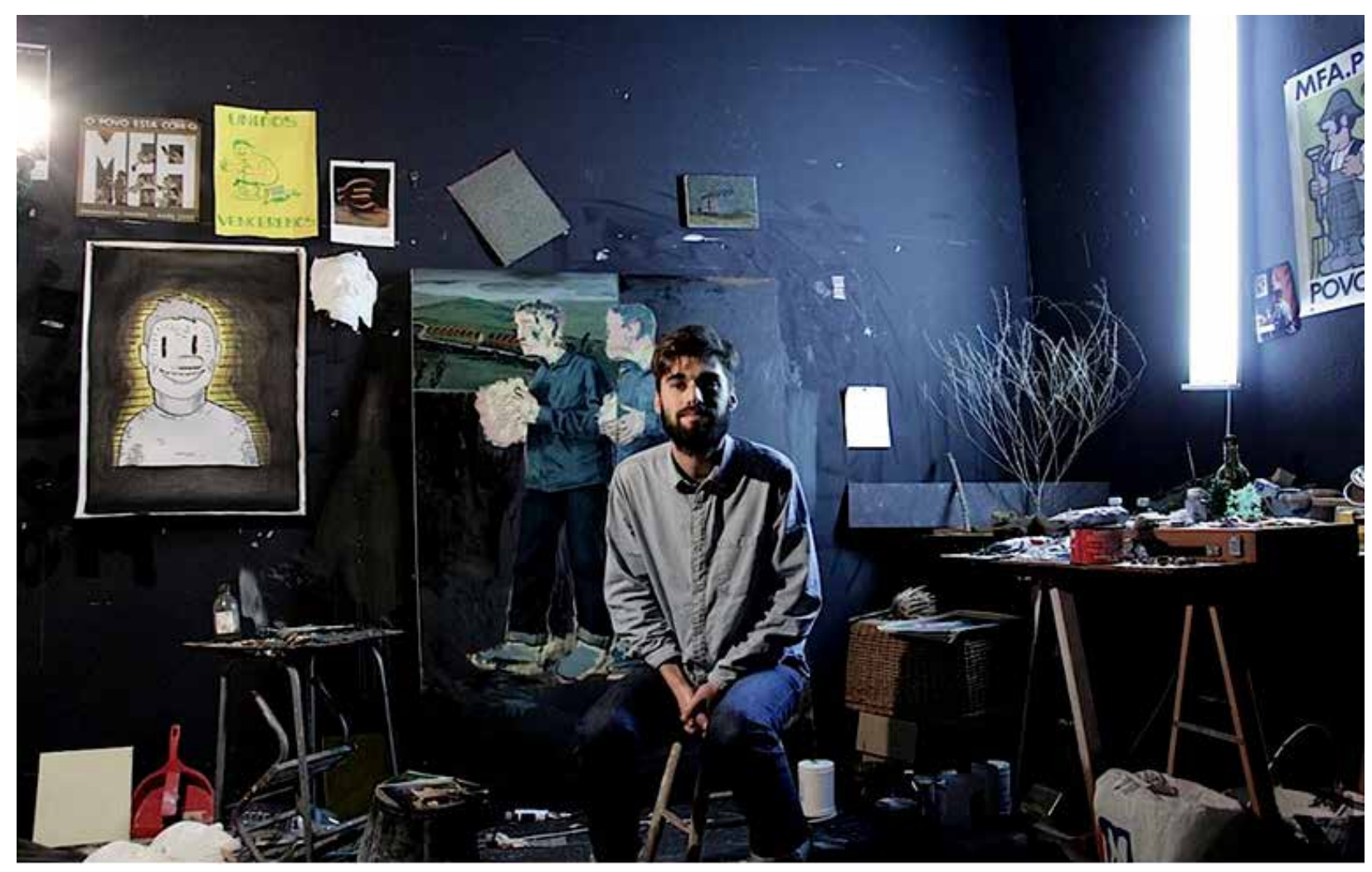

Figura 1 - Tiago Baptista.

e defendeu-as e dominou-as. No entanto, é na simplicidade da folha da couve que reside o espanto, na agressividade das silvas, no chão pantanoso, nas pequenas ervinhas que corajosamente existem nos solos. Aconteceu que existíssemos, tal qual ervas daninhas, espontaneamente sobrevivendo, falta agora o sentido, pois para além de transportarmos o dom da vida, carregamos o pensamento, o uso da razão. (Domingues, 2012)

Este artigo procurará dar a conhecer em maior detalhe a obra de Tiago Baptista, nos seus múltiplos desdobramentos, que incluem a pintura, o desenho, a banda desenhada, e até o cartaz. Ao longo deste percurso tornar-se-á evidente a vontade paradoxal de Baptista em mostrar não só um mundo no limiar do fracasso (paradoxalmente procurando resgatá-lo), mas também a convocação de influências da história da pintura, que enriquecem e tornam complexo o simbolismo presente nas suas imagens.

\section{Heróis que não o são}

O Narciso! O das Fossas, pode ser um qualquer produtor suinícola português. [;] Represento um senhor que se apaixona por si ao ver o seu reflexo numa fossa. Esta ideia surgiu numa viagem que costumo fazer para os lados do Cadaval e vejo lá ao fundo umas fossas a céu aberto, bem bonitas, e que pouco reflectem sem ser a ganância e falta de responsabilidade de quem fez com que essas crateras escavadas na terra, que servem para guardar dejectos de animais, existissem. (Baptista, 2010: Abril)

Esta pintura representa um sujeito, com pinta de futebolista gingão, símbolo da glória, da ascensão social e monetária [;] Este sujeito é um modelo, um módulo, um exemplo a seguir. Aparece aqui como um guardião, o porta-estandarte de uma cultura, o símbolo de uma nação - a Nação Portuguesa, terra de grandes feitos. Por de trás deste sujeito um rebanho espezinha um conjunto de livros. Esta personagem é também um guardador de rebanhos, um "Pastor". (Baptista, 2010: Abril)

A pintura de Tiago Baptista, mais que autobiográfica é geracional, no sentido de que traduz as ansiedades não de um individuo mas de uma geração e do que a toca de forma premente. Isto é notório na pintura de 2009, onde cria a figura do herói nacional, numa crítica clara que exprime tanto de forma visual como de forma escrita no pequeno texto explicativo que publica.

A personagem (o futebolista) de inspiração real, e facilmente reconhecível, apresenta-se como um símbolo nacional e portanto um modelo a ser seguido na representação dos valores de um 


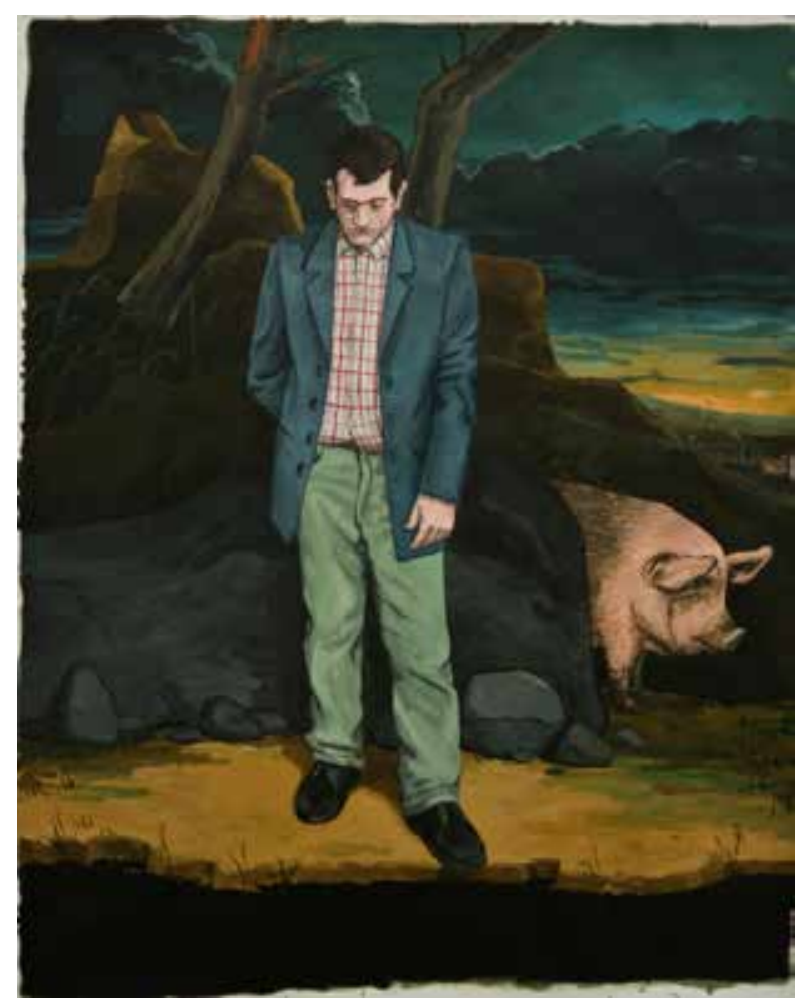

Figura 2 - Tiago Baptista, "O Narciso das Fossas", 2010, Acrílico sobre papel, $190 \times 150 \mathrm{~cm}$

país. Porém, o que vemos é uma figura mediática transformada num pastor (palavra também usada de forma insultuosa em determinados contextos, sendo símbolo de pequenez intelectual), que passeia um rebanho (uma nação?), sobre livros esquecidos ao longo do caminho, mostrando como perderam importância.

Um ano mais tarde, surge um "Narciso" numa nova demonstração de incredulidade social. Aqui, foi o lugar (as fossas do Cadaval) que reclamou a criação da personagem, que na sua contemplação narcisista, esquece um bem maior - o bem colectivo.

Lugares e os seus ocupantes relacionam-se e confundem-se nas mensagens visuais do artista. Se os lugares são ruínas, também as pessoas parecem vestígios de gente. Ora por ganância, arrogância ou egocentrismo, mas também por desespero, por má sorte, da qual não têm culpa. Estas personagem proliferam, num desfile de dificuldade em serem maiores que si mesmas.

Sobre "No Job", Tiago explica: "Bem; é um tipo a afogar-se em merda porque não tem emprego. [;]

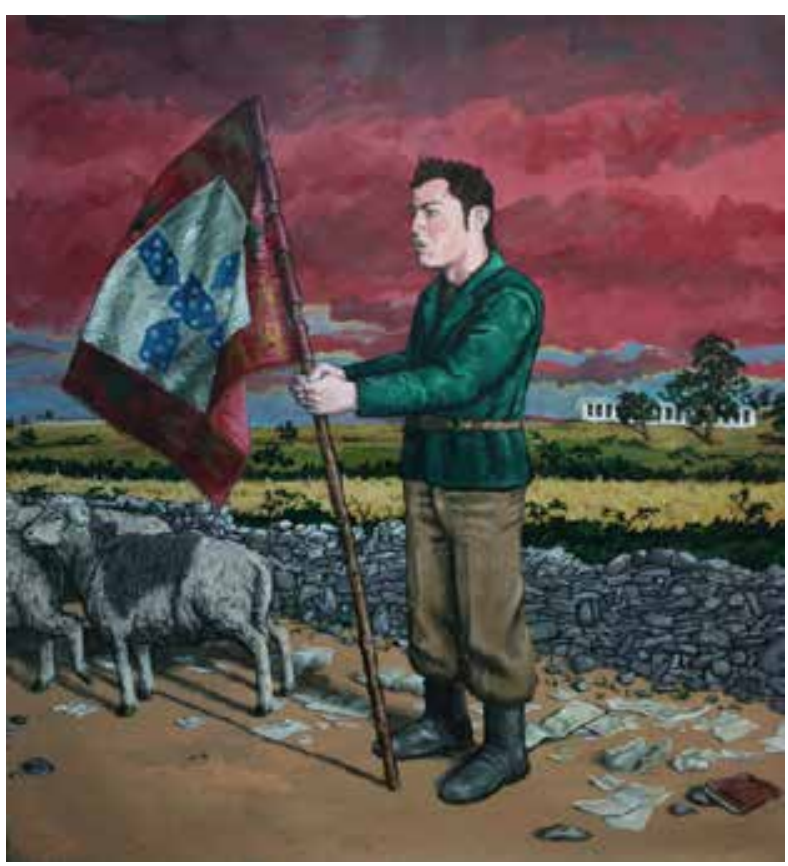

Figura 3 - Tiago Baptista, "O Herói Nacional", 2009, Acrílico sobre papel, $196 \times 200 \mathrm{~cm}$

O sujeito vê o mundo a acabar, as trevas a chegar, o desespero a possui-lo, o céu a fechar-se e a merda a sugá-lo para o fundo." (Baptista, 2009: Janeiro)

O mesmo desespero é evidente em "Sem Título" de 2010, onde num auto-retrato de rosto escondido, Tiago Baptista surge como alguém cansado de "atirar o barro à parede", alguém exausto de tentar, e que lentamente se vai tornando barro, e desaparecendo na sua fusão com este símbolo de fragilidade.

É paradoxal e desolador, que neste mundo de heróis que não o conseguem ser, tenhamos em duas extremidades distintas de um mesmo espectro, tanto a figura aparentemente respeitável que desilude e trai a sociedade, como o homem esforçado que não consegue corresponder às suas expectativas e às de outros.

O desfile continua. Num novo auto-retrato, um homem luta contra as silvas e talvez contra si mesmo:

Penso o momento labiríntico da experiência humana em que aquele que procura se deixa encurralar, gera a partir de si os obstáculos ao seu percurso, esse embate consigo mesmo em que as silvas aparecem do exterior amarradas a um interior complexo, um 


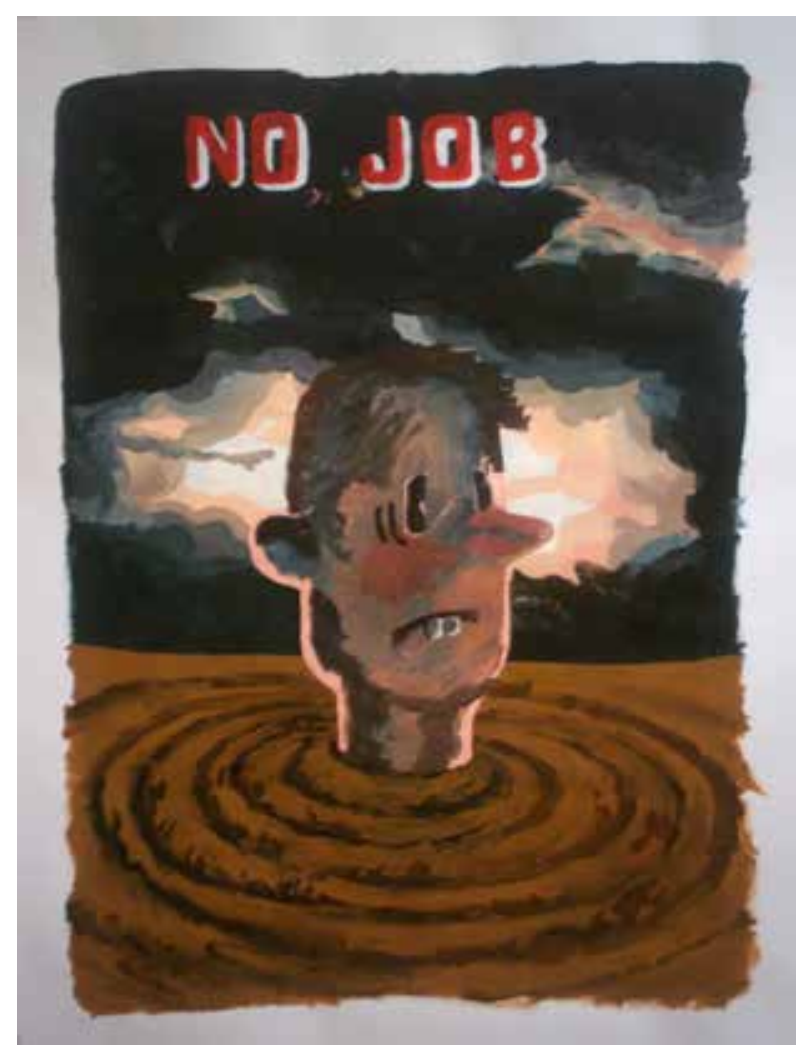

Figura 4 - Tiago Baptista, "No Job", 2009, Acrílico sobre papel, $140 \times 110 \mathrm{~cm}$.

emaranhado de silvas caindo levemente no corpo à espera de o ferir. (Domingues, 2012)

A pintura é também uma forma de reflexão pessoal, onde Baptista tenta descobrir o seu lugar no mundo e nos convida a descobrirmos o nosso. A sua pintura não é de todo centrada no ego, mas muito mais focada na experiência universal do que é ser humano, e de como por vezes, as nossas maiores dificuldades são criadas por nós e pela nossa dificuldade em sabermos existir num mundo que nos atraiçoa.

Na pintura "Sem Título" (2013) é mostrado um terreno dizimado pela desflorestação. Troncos decepados cobrem o terreno e duas personagens acusam-se mutuamente. Não há herói aqui, novamente. Não há chave que nos ajude a compreender qual dos dois homens carrega a culpa, porque a história contada é uma vez mais a história da falência humana e não a de um justiceiro, que eleve o padrão moral.

O que assola o universo criado por Tiago Baptista, parece ser um erro colectivo que nos condena não individualmente mas antes como um todo.

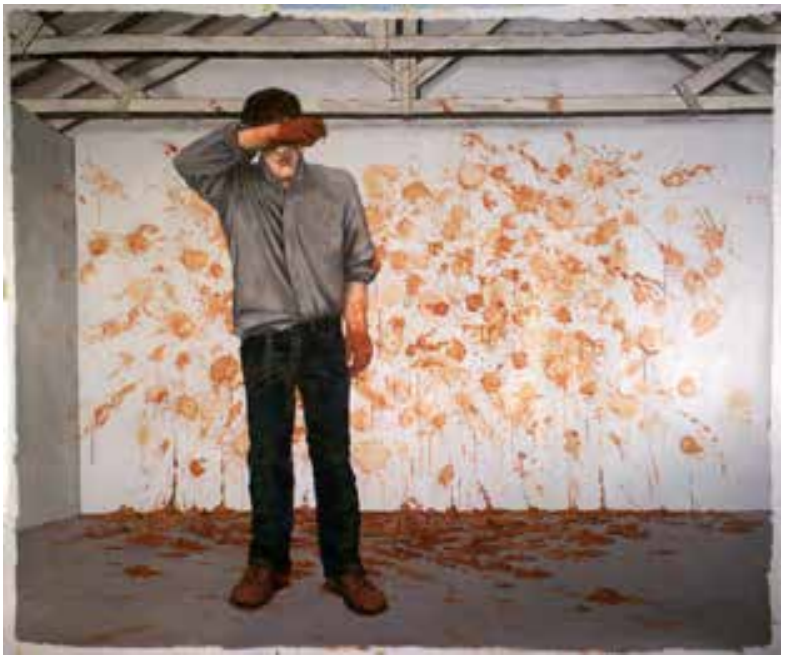

Figura 5 - Tiago Baptista, "Sem Título", 2010, Acrílico sobre papel, $190 \times 224 \mathrm{~cm}$.

Se o Narciso das Fossas é uma metáfora para o egocentrismo e a ganância, e o futebolista é um herói nacional que passeia ovelhas sobre livros, e é admirado pelas qualidades periféricas ao âmago social, existem também as personagens que perduram e com as quais nos conseguimos identificar. É certo que não são heróis redentores como se poderia esperar num mundo em decadência que se quer imaginar reerguido - são gente; pessoas reais com características boas, más, honestas. São gente que ainda não se desfez em barro, analogia querida a Baptista.

Para além da crítica bem presente, todo o imaginário patente rejeita a cidade enquanto símbolo de progresso ou desenvolvimento - e quando sinais deste surgem são, nas palavras do próprio autor "fábricas que mal funcionam (ou não funcionam de todo), casas esquecidas, caminhos inacabados (ou aproveitados/adaptados da erosão natural), pedras que foram deixadas ao acaso." (Baptista, 2011: Maio) Porém, todos eles contribuem para a criação e a sustentação deste universo de destruição. 


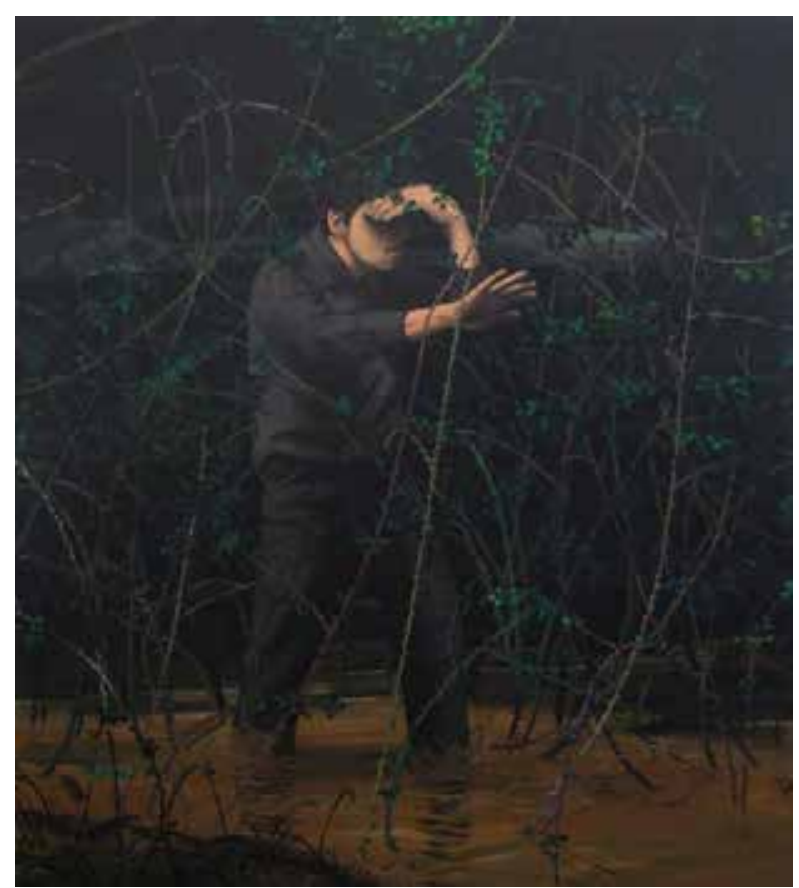

Figura 6 - Tiago Baptista, "Sem Título", 2012, Óleo sobre tela, $130 \times 110 \mathrm{~cm}$

O espaço é quase invariavelmente exterior, denso e carregado. As paisagens não se referem tanto a uma arcádia idealizada mas sim à paisagem rural portuguesa, frequentemente pontuada de pequenas fábricas e casas de pato bravo. (Poejo, 2010).

O universo fabril surge a cada passo, ora na forma de chaminés fumegantes que toldam a atmosfera, ora como lugares inertes, sem função. A eles juntase a lama escura ou a chuva e a neve, densa e húmida, construindo um mundo de abandono, ruína, desconforto e confronto com a condição humana.

O absurdo continua a caracterizar este mundo, em que os céus se fecham, levando com eles a sensação de esperança. As chaminés transformam-se em cigarros desmesurados, o espaço torna-se demasiado pequeno para o homem, o homem transforma-se em terra, barro, afogandose na paisagem. E num mundo devastado só ocasionalmente surgem sinais de vida que se compadecem da solidão humana: um animal ou outro, ou alguma vegetação que ganha escala e se afirma vertical, transformando-se no herói da história, na personagem principal que pela sua vivacidade verde parece mais forte e destemida do que qualquer espectro humano. A natureza ganha sempre, e nestas paisagens de Tiago Baptista, é ela que nos deixa espaço para respirar e pausar a

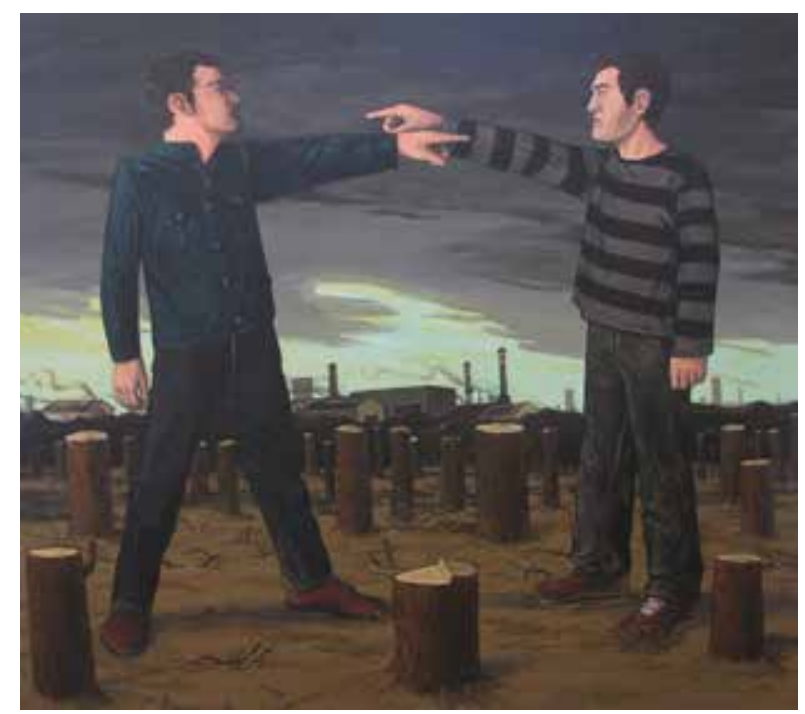

Figura 7 - Tiago Baptista, "Sem Título", 2013, Óleo sobre tela, $130 \times 190 \mathrm{~cm}$

ansiedade causada por todos os outros elementos.

Existem novamente pormenores que nos transportam para o interior de Portugal, e viajando pela A8, estrada conhecida do pintor nas suas viagens Lisboa/Leiria, ao ver fábricas fumegantes por entre pinhais e campos agrícolas, é tentador encontrar nas suas imagens alguns momentos fugazes de realidade.

Nas suas pinturas, sobretudo as que oferecem uma maior noção de espaço, os céus fechados parecem tornar-nos pequenos e claustrofóbicos. Como se nos vedassem a possibilidade de nos elevarmos. Só as couves se elevam.

Couves encantadas no seu reinado absoluto de serem enraizadas à vida. Nesse esplendoroso absoluto de apenas ser, viver e morrer, totalmente integradas na terra, erguidas para o tempo, acontecendo. Para além da imagem da couve, a sua força, a mesma que inspira cada ser, a respiração de existir em cada folha, em cada nervura, nas veias de viver. (Domingues, 2012).

São talvez as couves, as pequenas ervas, os fetos, pequenos seres acéfalos, que pela sua simplicidade e carácter inócuo se tornam os heróis deste mundo escuro. Salvadores que se limitam a existir, a crescer para além da lama, pintando de verde pequenos momentos mostrados pelo pintor. 


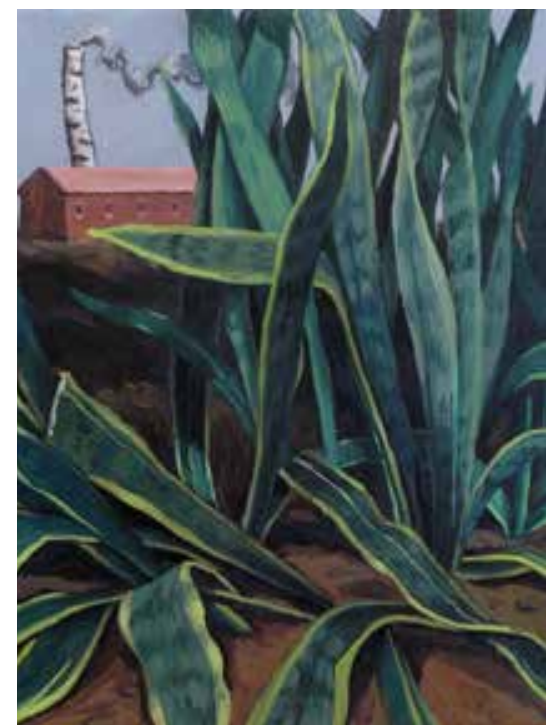

Figura 8 - Tiago Baptista, "Sem Título", 2013, Óleo sobre tela, $40 \times 30 \mathrm{~cm}$.

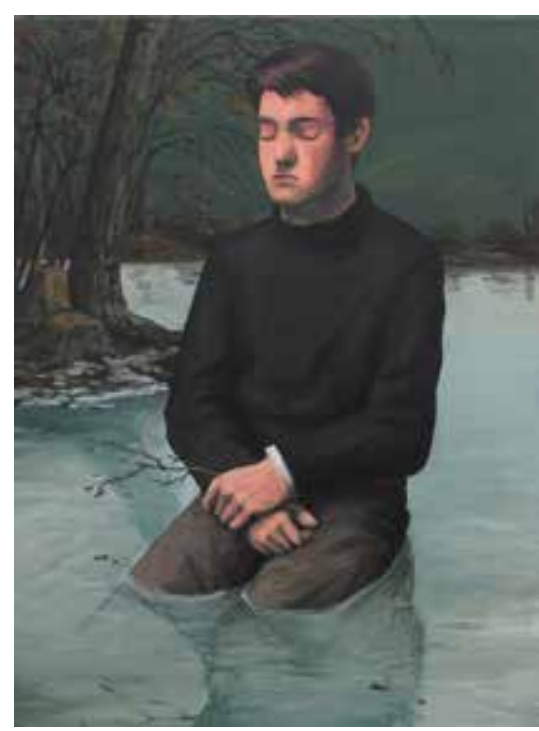

Figura 9 - Tiago Baptista, "Sem Título", 2013, Óleo sobre tela, $80 \times 60 \mathrm{~cm}$.

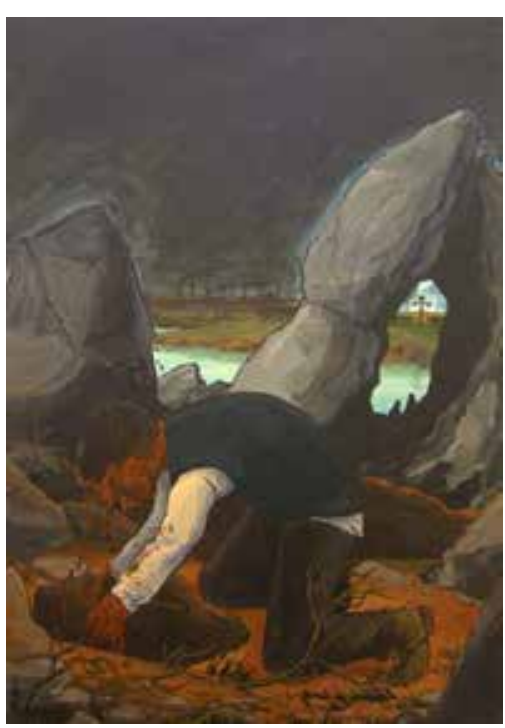

Figura 10 - Tiago Baptista, "Sem Título", 2011, Acrílico sobre tela, $61 \times 46 \mathrm{~cm}$.

\section{Histórias de homens e lendas da pintura}

A Tiago Baptista interessa "encenar uma acção que não seja facilmente descodificada, a possibilidade de inventar uma ou várias histórias em redor de cada personagem e das suas relações", como refere [...] As narrativas sucedem-se e o absurdo das pulsões não controladas e o exercício de uma vontade elementar, descrita em curtos e sintéticos rasgos visuais, remetem-nos para uma literatura que tem em Edgar Alan Poe, Max Aub ou, até, num dado mais deprimido e extenso mas, por vezes, presente, Dostoievsky, grandes representantes. (Faro, 2009: 54).

Pedro Faro, num artigo publicado na extinta revista L+Arte, chamou às narrativas e personagens de Baptista crimes exemplares. São somente crimes pelas histórias que contam e exemplares pela forma verdadeira como são contados. Sobre estes atributos Faro relembra as palavras de Max Aub:

Os homens são aquilo em que os tornaram, e querer considerá-los responsáveis por aquilo que os leva, de repente, a ficar fora de si é uma pretensão que não partilho. As razões evidentes que os levaram ao crime são fornecidas por eles próprios com uma fraqueza total, pois não têm outro desejo para além de se deixarem, por vezes, arrebatar pelo seu infortúnio. (Aub apud Faro, 2009: 54).

Olhando com atenção, podemos perceber que as histórias contadas por Tiago Baptista têm diferentes níveis de narração. Existe sempre uma história maior, já identificada: a de uma falha que, pensando em Aub, é, para além da culpa individual do sujeito, culpa também do colectivo onde este se insere e até mesmo da natureza que assim o fez.

Existem pistas de lugares, de acontecimentos, às vezes pistas de pinturas por outros pintadas. Existe a história de Tiago que transparece nos lugares e pessoas escolhidas e nos temas trabalhados. E por fim, a história que visivelmente se conta na pintura, que muitas vezes é apenas desvendada o suficiente para ser identificável, mas que pede ao observador que a descubra, e reflicta sobre ela. Há um mundo de possibilidades, simbólicas e contemplativas, em cada imagem e referências claras à pintura clássica e às lendas da pintura.

$\mathrm{Na}$ pintura "Redenção era morrermos todos queimados", há uma alusão evidente à pintura "Et in Arcadia Ego" (1639) de Nicolas Poussin, porém essa alusão não se transforma numa mera transposição para a contemporaneidade. Se Poussin nos alerta para a impossibilidade de escaparmos da morte, pois até em Arcadia ela está presente, Tiago Baptista assume logo à partida que escapar à morte é uma batalha perdida, e que os horrores em que a humanidade se envolve são apenas passíveis de redenção com o nosso desaparecimento. Aos mais atentos não escapará o avião e o míssil esculpidos em pedra, na base da imagem, numa clara alusão aos conflitos deste e do século passado.

As suas evocações de antigos mestres são diversas, como se pode confirmar também quando o cordeiro 


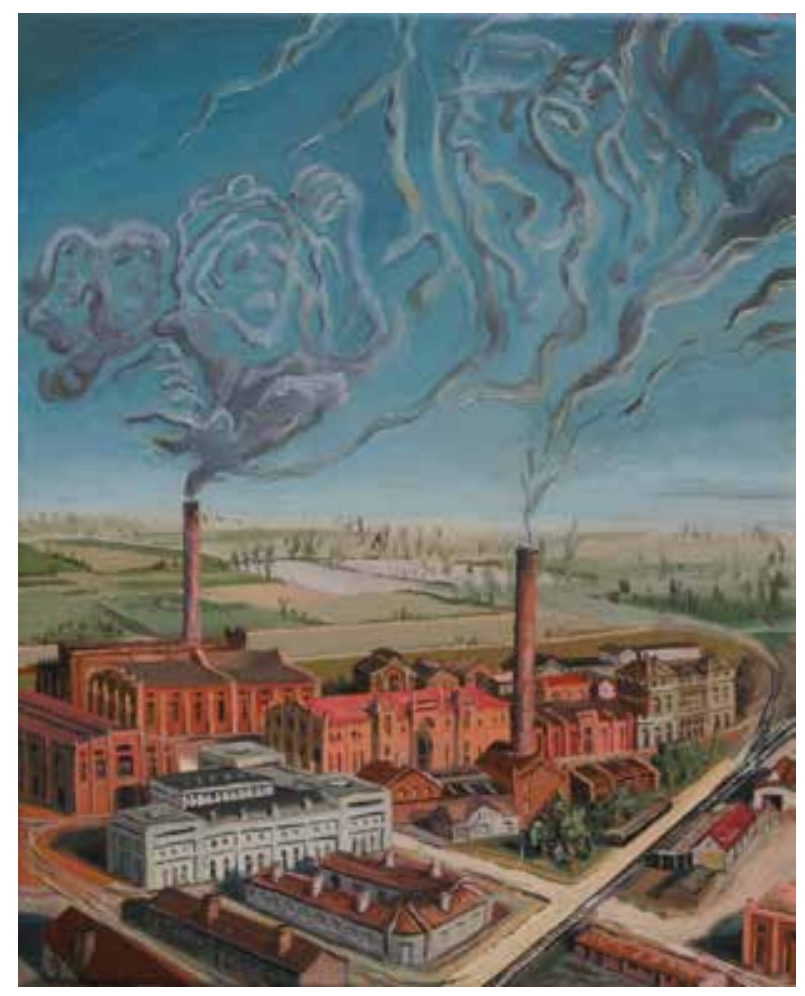

Figura 11 - Tiago Baptista, "Sem título", 2015, Acrílico sobre tela, $80 \times 60 \mathrm{~cm}$.

de Josefa d'Óbidos é representado a afogar-se num escuro poço negro. De certa forma, é como se $o$ artista se identificasse mais com imagens e personagens bucólicas do passado, plenamente consciente da inadequação destes ao momento contemporâneo, o que de certo modo contribui para a sensação de absurdo ou surrealidade já antes apontada.

Durante um longo período, Baptista debruçou-se também sobre a simbologia do barro:

Segundo textos bíblicos Deus disse: "Até que voltes à terra de onde foste tirado porque tu és pó e ao pó voltarás". A divindade condena o Homem à vida de esforço e privação alertando-o também para a sua fragilidade e efemeridade na terra. Apesar da Humanidade ser feita do pó da própria terra misturado com água e, apesar da terra ser a matéria de origem, ela é também símbolo do fim da nossa existência. [...] Estas pinturas, estas imagens, com estas figuras de "formas amassadas", estes "corpos de barro", são "visões" de como seriam os seres humanos se uma entidade mística os transformasse em barro. Este material frágil, de consistência dúbia funciona como metáfora da instabilidade, da fraqueza dos Homens, reflexo dos seus comportamentos sociais e das suas decisões. (Baptista, 2011: Maio).

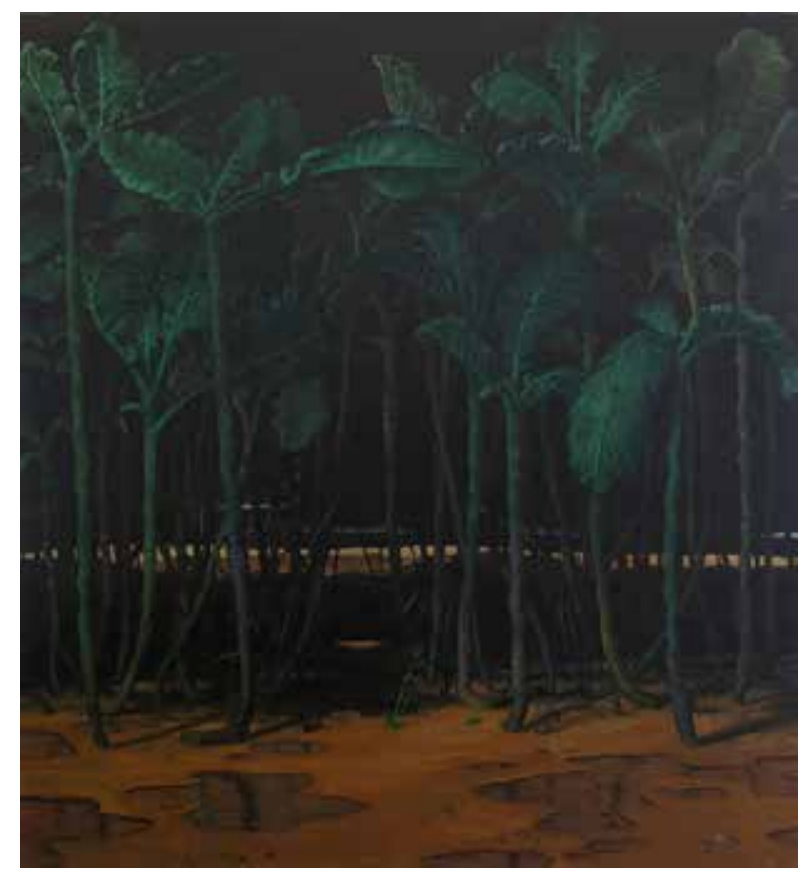

Figura 12 - Tiago Baptista, "Sem Título", 2012, Acrílico sobre tela, $190 \times 130 \mathrm{~cm}$.

As imagens que criou procuram, através das suas analogias a este material, evidenciar uma dualidade humana. Existe uma antiga tradição na identificação do barro ou da terra como matéria criadora do homem, transversal a diversas culturas geograficamente dispersas, que o artista conhece bem. Como o próprio artista aponta, o barro é um material que apresenta uma estranha ambiguidade, sobretudo na tradição artística. É simultaneamente um médium frágil e instável que se parte e desfaz, e é porém um dos materiais mais expressivos numa simbologia ligada à criação, estando inclusivamente visado na Lenda do Nascimento da Pintura (e também da Escultura), descrita por Plínio-o-Velho.

Na pintura "Sem Título" de2011, quatro personagens transformam-se em barro. A fraqueza, que o artista aponta no texto supra-citado, começa a instalar-se, a apoderar-se também dos que the eram alheios, como uma condenação contagiosa que se propaga e nos desfaz - um início do regresso ao chão; Esta pintura é talvez uma metáfora de um tipo de morte que nos atinge quando não concretizamos plenamente o nosso potencial. É desta incapacidade que somos acusados, ou alertados, a cada imagem 


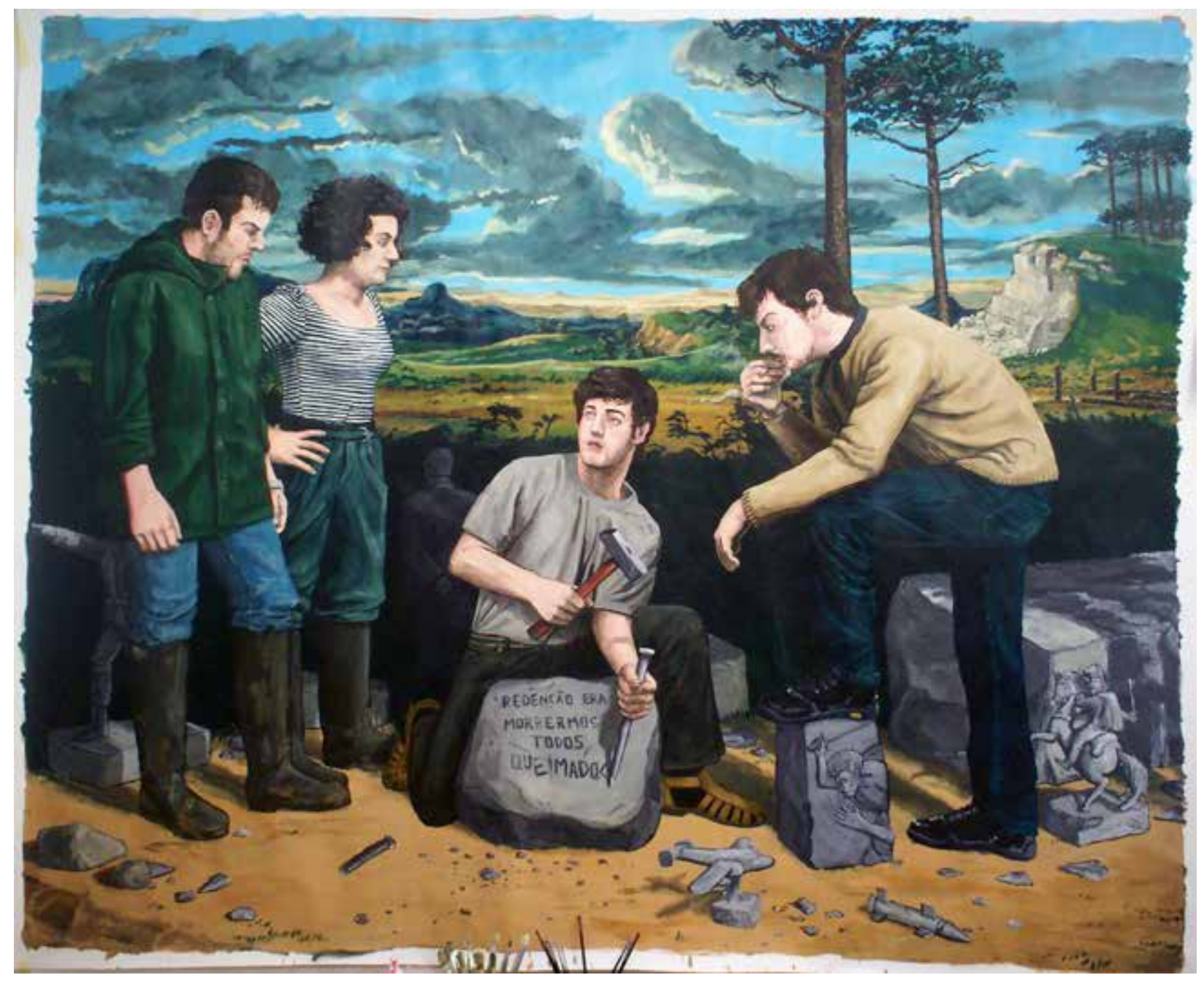

Figura 13 - Tiago Baptista, "Redenção era morrermos todos queimados", 2010, Acrílico sobre tela, $213 \times 255 \mathrm{~cm}$.

criada por Tiago.

Se tal como o barro a humanidade é dual, a falha, o erro e o fracasso, fazem tanto parte de si, como a força de espírito, a honestidade, a dignidade. Existem com igual relevância. Talvez por isso, em cada pintura há uma atmosfera de ocaso, de tempo que se esgota e se torna irrepetível - quase como se Baptista tentasse recordar-nos que a humanidade é mortal, e o tempo de tentar mudar (mesmo dentro da nossa imperfeição) é agora.

Por último, um pequeno olhar sobre a pintura "Pas de lumiére", onde debaixo de um manto, com uma luz acesa, um homem caminha pela escuridão. Vimos antes como muitas personagens que atravessam estas pinturas parecem fazê-lo em esforço, e muitas de olhos vendados ou fechados. É inevitável ver nestas posturas associações com a história da pintura, onde a luz como fonte de visibilidade permite a aceitação da figuração como garante do real. É a cegueira dos que fecham ou escondem os olhos, uma metáfora para a nossa falta de vontade em ver a realidade? É a atitude deste homem coberto por um manto iluminado, um primeiro indício de esperança, de que aos poucos aprenderemos a ver? É o próprio manto, riscado de cores primárias, um indicador de que a pintura pode ser a capa protectora com que aprendemos a encontrar o nosso caminho? Uma vez mais, Tiago Baptista coloca-nos todas as perguntas, mas deixa para cada um encontrar as suas próprias respostas, nesta amálgama de símbolos que nos deixam em constante estado de alerta.

Tiago Baptista é, pode dizer-se, um pintor "à moda antiga". Ao seu trabalho pictórico agrega a criação gráfica, por vezes preparatória, por vezes com vida 


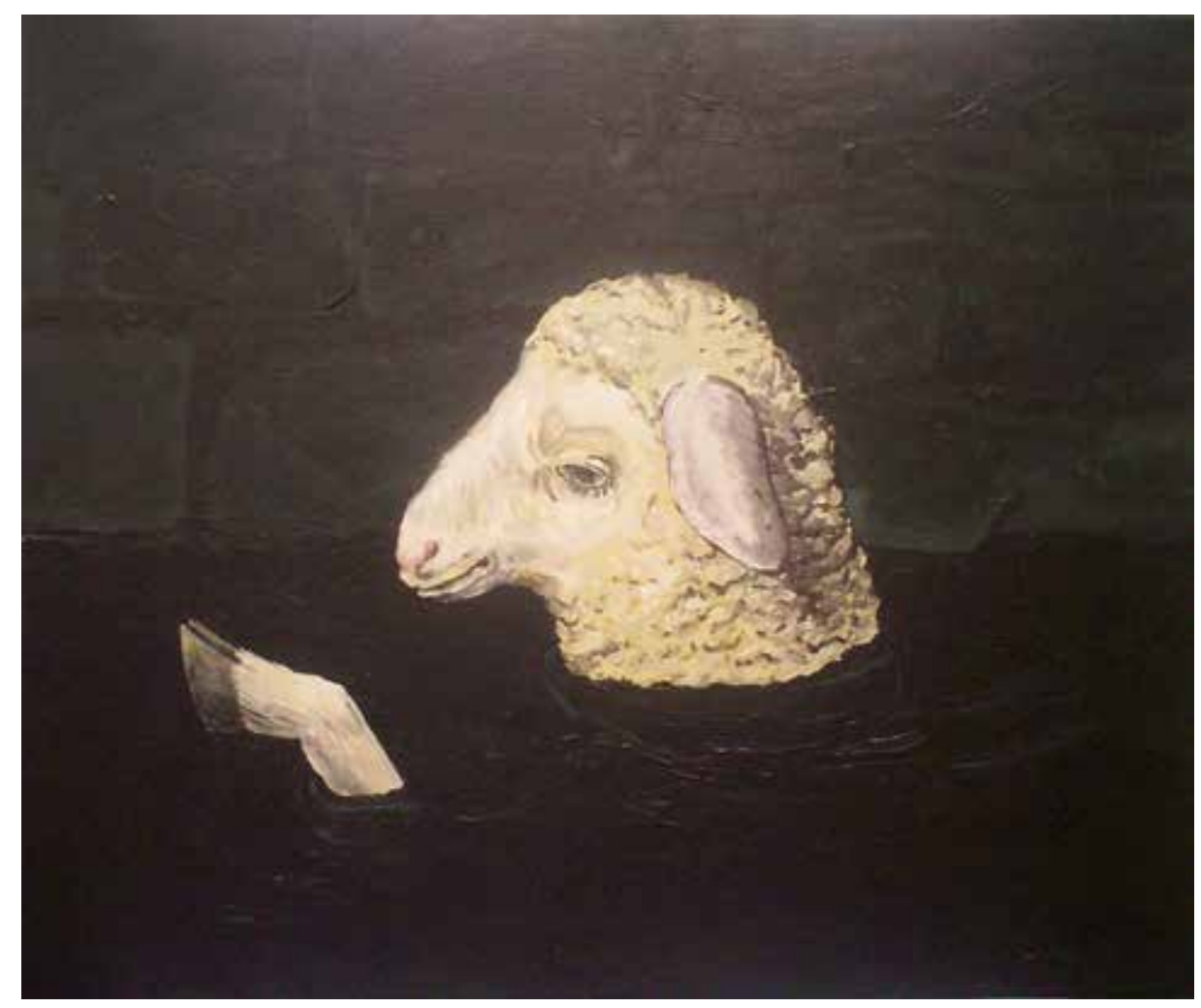

Figura 14 - Tiago Baptista, "Cordeiro", 2005, Acrílico sobre tela, $30 \times 40 \mathrm{~cm}$.

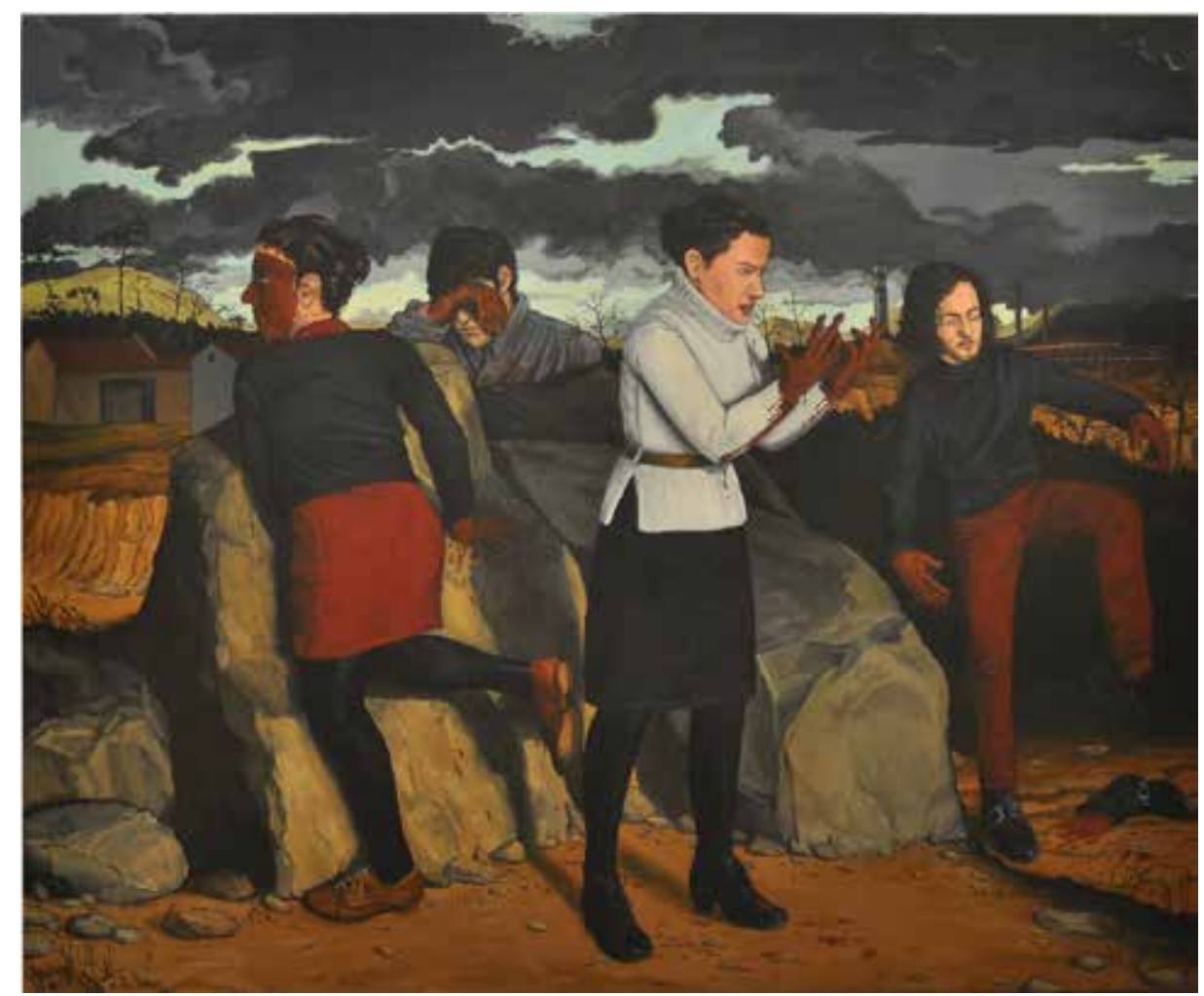

Figura 15 - Tiago Baptista, "Sem Título", 2011, Óleo sobre tela, $130 \times 190 \mathrm{~cm}$. 


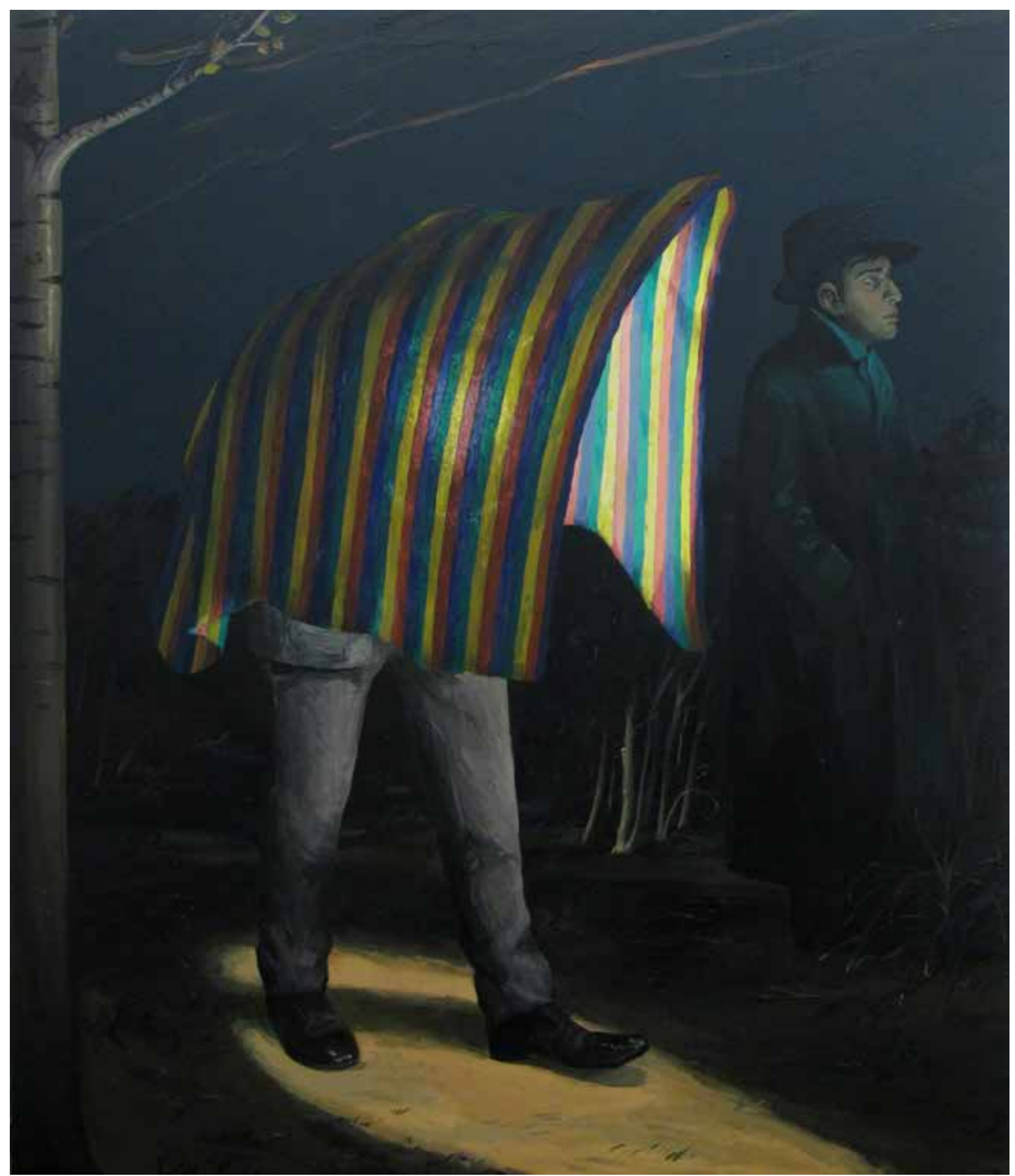

Figura 16 - Tiago Baptista, "Pas de lumiére", 2015, Óleo dobre tela, $160 \times 170 \mathrm{~cm}$. 


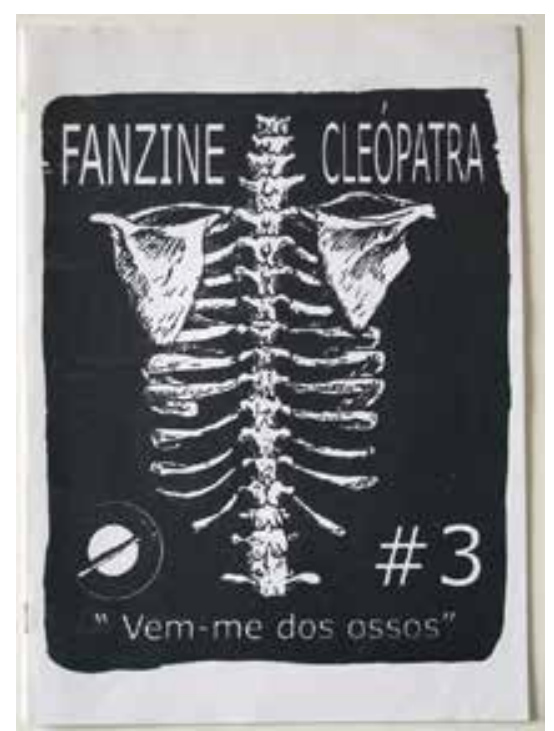

Figura 17 - Tiago Baptista, Cleópatra \#3, 2008, 16 páginas, $30 \times 21 \mathrm{~cm}$.

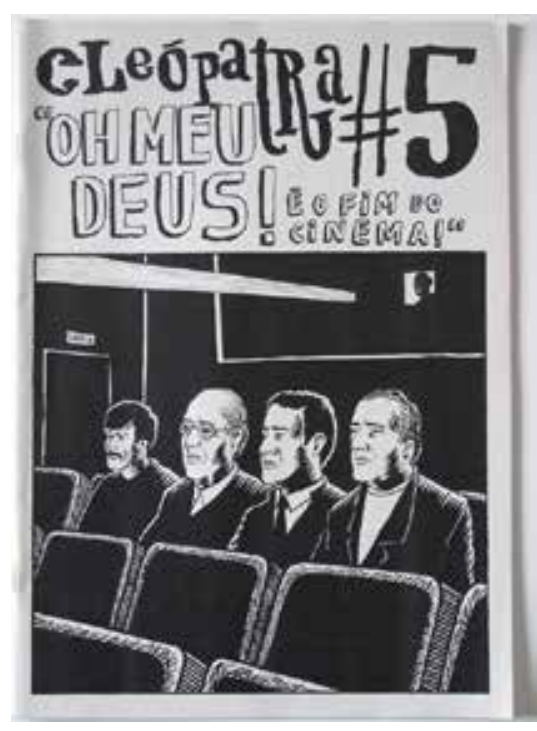

Figura 18 - Tiago Baptista, Cleópatra \#5, 2011, 32 páginas, 30×21 cm.

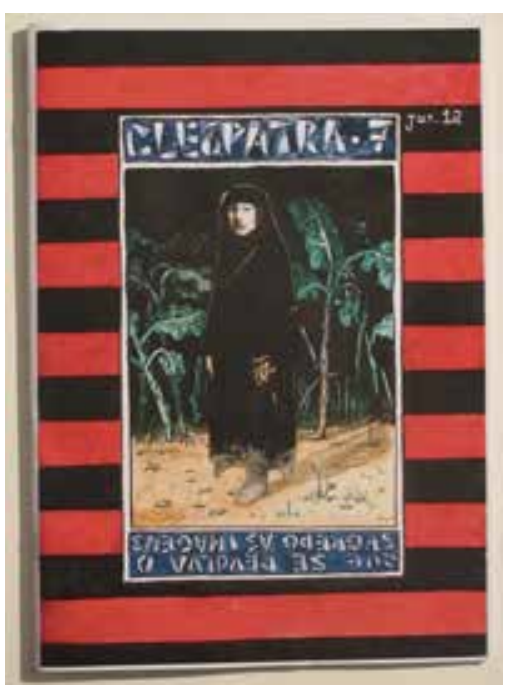

Figura 19 - Tiago Baptista, Cleópatra \#7, 2012, 44 páginas, $30 \times 21 \mathrm{~cm}$.

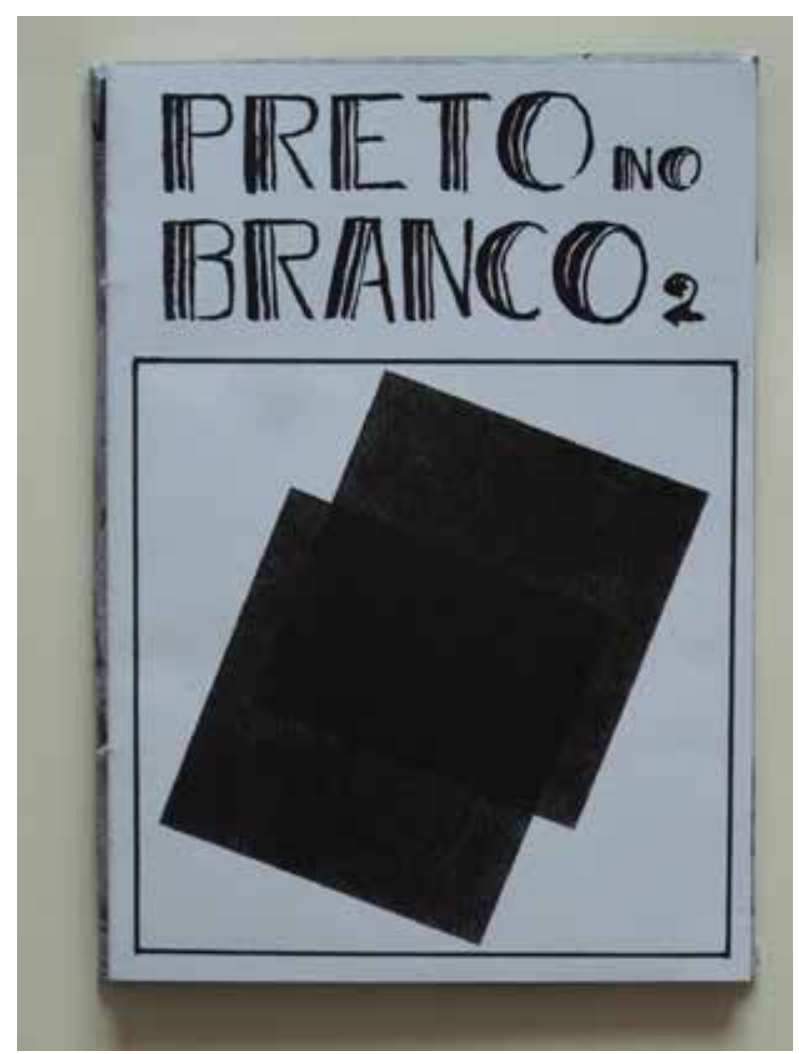

Figura 20 - Tiago Baptista, Com imagens de: Ana Biscaia, André Pereira, Bruno Borges, Catarina Domingues, Eduardo Ferreira, Isabel Ferreira,Patricia Guimarães, Pola Dwurnik, Sílvia Prudêncio e Tiago Baptista. "Preto no Branco N)2", 2013, 64 páginas, $20 \times 14,5 \mathrm{~cm}$.

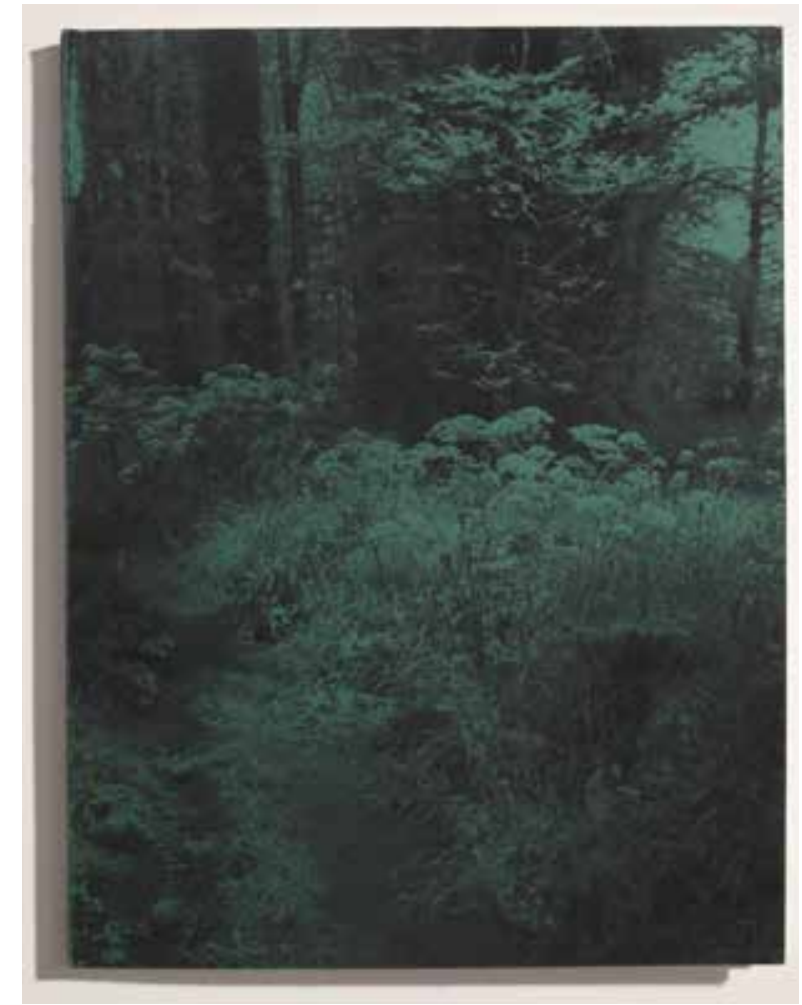

Figura 21 - Catarina Domingues, "Respiração", 2012, 40 páginas, $18 \times 14 \mathrm{~cm}$. 
própria, a elaboração de cartazes, e a direcção de uma editora independente: Façam Fanzines e Cuspam Martelos. Em cada criação, a sua coerência e autenticidade é evidente, criando uma aura nostálgica de pintor fiel à tradição da história da pintura, que se torna curiosa em pleno século XXI.

\section{Façam fanzines e cuspam martelos}

Comecei por sublinhar a forma como Tiago Baptista transformou a sua pintura num acto socialmente interventivo. É nessa linha que surge "Façam Fanzines e Cuspam Martelos", a editora independente de Tiago, que regularmente publica fanzines da sua autoria e de outros artistas.

\begin{abstract}
O nome que dei à editora que se apresenta formalmente neste sítio apareceu pela primeira vez no fanzine "Bolso \#4" em 2006, pensei que seria um nome que transmitia uma sensação de esforço (escatológico?) e que dava o mote para a actividade fanzinista como sendo algo que tem que ser expelido, mas que custa sair. Cuspir martelos pareceu-me algo que traria alguma dor a quem os cuspisse. Como os fanzines. Costumo pensar nestas publicações como uma disputa com o tempo, com o esquecimento. Mesmo que muito pouca gente ou ninguém leia fanzines, eles existem para o mundo, são o legado da nossa existência, são a projecção dos nossos sonhos, ansiedades, preocupações, objecções e sentimentos. Os fanzines, punhado de folhas agrafadas, tal como outras formas de criação artística são como uma espécie de imortalização do espírito. Essa ideia de publicar mais ou menos precária e instável, existe sem razão, sem explicação, sai de dentro para fora. (Baptista, 2012: Abril).
\end{abstract}

"Cleópatra", a mais antiga das publicações, começou a ser publicada em 2006, sendo quase um livro de artista, sempre pensado, concebido e produzido por Tiago Baptista, associa imagens, desenhos e bandas desenhadas onde, como nas pinturas, os universos de interesse se fundem, por vezes denotando fortes referência da história da arte, mas criando novas leituras.

"Preto no Branco", publicado desde 2012, conta com a colaboração de vários artistas convidados, mantendo a regra que o nome indica: todas as imagens são a preto e branco, uniformizando esteticamente a edição. É a filha de uma anterior publicação chamada "Besta Quadrada", que terminada em 2009 se reconfigurou e deu origem a um novo projecto. Para trás ficou também a publicação "Facada".

A editora tem sido uma plataforma relevante para o lançamento de outro tipo de publicações de edição única. Dessas destacam-se "Fábricas, baldios, fé e pedras atiradas à lama" de Baptista, mas também "Respiração" de Catarina Domingues, "Coveiro, é belo contemplar as ruínas das cidades; mas é mais belo ainda contemplar as ruínas dos humanos!" de André Catarino e "Stabat Mater" de Patrícia Guimarães.

O dinamismo da editora "Façam Fanzines e Cuspam Martelos" é o dinamismo do próprio Tiago Baptista, que de forma atenta continua a inscrever-se no mundo, deixando que este se inscreva nele. Podemos não encontrar esperança nas imagens que Tiago cria, mas encontramos boa pintura, e isso, para alguns, é uma forma de resgatar um pouco do mundo.

\section{REFERÊNCIAS}

BAPTISTA, Tiago - "Blogue do Tiago Baptista"

Disponívelem<URL:http://bloguedotiagobaptista. blogspot.pt/

BAPTISTA, Tiago - "Fanzines e Martelos"

Disponível em <URL: http://www. fanzinesemartelos.blogspot.pt/p/o-que-e-isto. html

DOMINGUES, Catarina - "O que fazer com isto?". Livro de sala. Lisboa: Galeria 3+1, 2012

FARO, Pedro - "Crimes Exemplares". In Revista L+Arte N)61. Lisboa: Saúde Press, 2009

POEJO, André - "Um dia destes;". Folha de sala. Galeria 3+1, 2010

\section{SOBRE A AUTORA}

Susana Rocha é artista plástica e investigadora académica. Doutoranda em Belas-Artes pela Faculdade de Belas-Artes da Universidade d Lisboa - Portugal. Bolseira no âmbito de uma Bolsa Individual de Doutoramento da Fundação para a Ciência e Tecnologia (FCT). Investigadora Associada ao CIEBA-FBAUL. Mestre em Pintura e Mestre em Ensino de Artes Visuais. Licenciada em Pintura. Frequentou Residências no Rio de Janeiro (Brasil), Ólafsfjordur (Islândia) e Lisboa (Portugal). Participou de diversas exposições e mostras nacionais e internacionais. Reside e trabalha em Lisboa. 